PERSPECTIVA TEOLÓGICA ADERE A UMA LICENÇA CREATIVE COMMONS ATRIBUIÇÃO 4.0 INTERNACIONAL - (CC BY 4.0 )

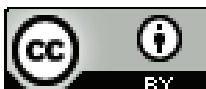

DOI: $10.20911 / 21768757 v 52 n 3 p 681 / 2020$

\title{
A ACOLHIDA E O LUGAR DO CORPUS JOANINO NO CÂNON DO NOVO TESTAMENTO
}

\author{
The Reception of the Johannine Corpus and its Place in the New Testament Canon
}

Waldecir Gonzaga *

RESUMO: Este artigo visa a oferecer um estudo acerca da acolhida do corpus johannicum e de seu lugar no conjunto dos textos do Novo Testamento, visto que o mesmo tem suas particularidades próprias, a começar pelo fato de que não é um corpus "coeso", que traga seus livros numa sequência, como temos, por exemplo, com as cartas paulinas. Ele conta com três gêneros de literatura bíblica, a saber: Evangelho, Carta/Epístola e Apocalipse. O corpus joanino, desde a Igreja Primitiva, sempre encontrou uma certa resistência no que tange à aceitação de mais da metade de seus textos, todos atribuídos a João Evangelista, no que diz respeito à sua autoridade apostólica. Ele conta com apenas cinco textos: um Evangelho, três Cartas e um Apocalipse. O Evangelho de João sofreu muitos ataques e acusações como sendo um texto pró-gnóstico; a segunda e a terceira cartas custaram a ter aceitação plena no cânon bíblico; o livro do Apocalipse foi aceito pela Igreja Ocidental e recusado pela Igreja Oriental, até que, por volta do final do séc. IV, finalmente entrou no cânon do NT. A primeira carta encontrou maior e mais fácil aceitação logo de início.

PALAVRAS-CHAVE: Corpus Joanino. Cânon. Evangelho. Cartas. Apocalipse.

ABSTRACT: The aim of this article is to study both the reception of the corpus
johannicum and its place among the New Testament texts. The corpus johannicum
has its particularities, beginning with the fact that it is not a "cohesive" corpus in
which the books appear in a sequence as in, for instance, the Pauline letters. The
corpus johannicum has three biblical literary genres, namely: Gospel, Letter/Epistle
and Revelation. In the early Church, most of its texts faced resistance regarding

* Pontifícia Universidade Católica do Rio de Janeiro, Rio de Janeiro, Rio de Janeiro, Brasil. 
their effective attribution to John the Evangelist. This corpus has only five texts: a Gospel, three Letters and an Apocalypse. The Gospel of John was accused of being a pro-gnostic text; the second and third letters took a long time to gain full acceptance in the biblical canon; the book of Revelation was accepted by the Western Church and rejected by the Eastern Church until the end of the 4th century, when it finally became accepted in the canon of the New Testament. The First Letter had easier acceptance from the outset.

KEYWORDS: Johannine corpus. Canon. Gospel. Letters. Apocalypse.

\section{Introdução}

$\mathrm{O}$ Novo Testamento conta com vinte e sete livros, tendo uma divisão em blocos, que é clássica desde o Período Patrístico, hoje comumente aceita por católicos, ortodoxos e protestantes (BROWN; COLLINS, 2011, p. 925), a saber: os quatro Evangelhos (Mateus, Marcos, Lucas e João); o livro dos Atos dos Apóstolos; as treze cartas Paulinas (Romanos, 1 Coríntios, 2 Coríntios, Gálatas, Efésios, Filipenses, Colossenses, 1 Tessalonicenses, 2 Tessalonicenses, 1 Timóteo, 2 Timóteo, Tito e Filemon); a carta aos Hebreus; as sete cartas Católicas (Tiago, 1 Pedro, 2 Pedro, 1 João, 2 João, 3 João e Judas) e o livro do Apocalipse. Outra forma de classificar os textos do NT é aquela, igualmente clássica, de identificar os diversos corpora por autoria ou por gênero literário, de tal forma que temos: o corpus sinótico, o corpus paulino, o corpus católico e o corpus joanino.

A disposição do arranjo dos quatro corpora neotestamentários, embora seja clássica, depara-se com o fato de que este corpus biblicum não é composto por textos de um único gênero de literatura bíblica. Se isso é verdadeiro para o conjunto do inteiro NT, o é igualmente para o corpus joanino, pois os textos atribuídos a João Evangelista são os mais diversos possíveis, visto que eles estão distribuídos entre os diversos corpora e gêneros literários neotestamentários, a saber: entre os Evangelhos, as Cartas/Epístolas e um Apocalipse (HAAG, 1971, v. I/2, p. 93-97)1. Aliás, é bom recordar que João é o único autor do NT com essa categoria, pois os demais se enquadram apenas dentro de um único gênero literário. Ele navega bem pelos três gêneros presentes no corpus canonicum Novi Testamenti, sendo o único autor a trazer um Apocalipse. Como bem expressa Collins:

O Ap é um livro singular no NT. Os Evangelhos e Atos dos Apóstolos são, em sua maior parte, narrativa realista. As epístolas são basicamente prosa expositiva e exortativa. O Ap difere de tudo isso por ser uma narrativa de um tipo especial. Ele narra visões e audições extraordinárias que dizem respeito

\footnotetext{
${ }^{1}$ Pontifícia Universidade Católica do Rio de Janeiro, Rio de Janeiro, Rio de Janeiro, Brasil, p. 10).
} 
a coisas que normalmente não são vistas nem ouvidas por seres humanos. $\mathrm{O}$ Ap é singular no NT, mas não no mundo antigo (2011, p. 835).

Nesse sentido, o cristianismo joanino, com convivência cristã mista entre gentios e judeus, soube assumir mais cedo e melhor que ninguém os gêneros de escritos que foram surgindo no período do NT. Segundo Boring:

A Comunidade Joanina é o mais antigo grupo de igrejas, de que temos conhecimento, que expressou sua fé tanto no gênero Epistolar quanto no gênero Evangelho. Esses gêneros literários não se misturam facilmente, uma vez que representam maneiras fundamentalmente diferentes de conceituar o evento-Cristo (2016, v. II, p. 1121).

Os escritos Joaninos são assim chamados por serem atribuídos à pessoa de João, filho de Zebedeu, que a antiga tradição identificava com "o discípulo que Jesus amava". Nenhum dos cinco escritos do Corpus Johannicum afirma ter sido escrito pelo apóstolo João, filho de Zebedeu, porém faz parte da tradição e de atribuição à opinio communis (HILL, 2006). Porém, nós não sabemos ao certo qual a real participação da autoria do Evangelista ou qual o grau de colaboração de outros autores, como da Escola Joanina ou da Comunidade Joanina (BORING, 2016, v. II, p. 1120). Nem mesmo de um secretário do Apóstolo ou de alguém que mais tarde tenha redigido algum desses cinco escritos e o tenha atribuído a João Evangelista, ou tenha aprimorado os escritos, em suas várias fases de redação. Dessa forma, o Evangelho parece ser anônimo (Jo 21,24: "discípulo amado"); das três Cartas, a $1^{\underline{a}}$ seria de João, o Apóstolo, e a $2^{\underline{a}}$ e a $3^{\underline{a}}$ seriam de João, o Presbitero; e o Apocalipse seria de João, o Apóstolo (Jo 1,1.4) (FEUILLET, 1968, v. IV, p. 313; BORING, 2016, v. II, p. 1120,1124).

Admitir a existência de uma Escola Joanina significa reconhecer que existiram etapas no processo de redação dos escritos atribuídos a João (O'CALLAGHAN, 2000, p. 56), bem como uma comunidade que conservou esses escritos como sendo seus, dentro da tradição das várias correntes presentes no cristianismo primitivo. Entre suas características, há o fato de que esses textos da tradição joanina, atribuídos ao "divino teólogo". Eles foram escritos com os pés no chão da história e a partir de uma meditação luminosa e confiante nas mãos de Deus, que, em seu amor infinito, rege e governa o mundo, como se seu autor se encontrasse numa radiante liturgia (CULLMANN, 2012, p. 81), diante de seu Mestre e Senhor.

Embora os cinco textos joaninos tenham sido atribuídos a uma pessoa, escola ou comunidade joanina, eles nunca foram colocados todos juntos, num só grupo e na mesma sequência, por reinvindicações de autoria, como o corpus paulinum. Enfim, não é objetivo deste artigo trabalhar a questão da autoria ou datação dos textos atribuídos a João - embora se acabe tocando também nesses temas -, mas sim sua acolhida e seu lugar no cânon do NT, com sua pertença a um grupo específico de textos atribuídos a 
um autor do período neotestamentário. Esses escritos testemunham que existia uma corrente ou comunidade joanina na Igreja Primitiva (PENNA, 2014, p. 83), que foi conservando seus escritos preferidos, ligados à figura do Discípulo Amado, o apóstolo preferido deste grupo do cristianismo primitivo. Posteriormente, foram aceitos por todos os cristãos, a exemplo do Evangelho de João².

\section{$1 O$ corpus joanino no corpus do NT}

\subsection{Parentesco entre os textos joaninos}

O parentesco entre os textos joaninos é muito maior entre o Evangelho e as Cartas que entre eles e o Apocalipse (TUÑI; ALEGRE, 1999, v. 8, p. 155). Aliás, "a relação entre o Ap e o Evangelho de João é um problema complexo" (COLLINS, 2011, p. 838). Alguns chegam a afirmar que o parentesco entre os escritos joaninos é algo muito difícil de ser estabelecido (TUÑI; ALEGRE, 1999, v. 8, p. 11). A Tradição também viu uma certa proximidade entre os escritos joaninos, embora seja difícil de se estabelecer um contato entre todos eles (FEUILLET, 1968, v. IV, p. 226; PERKINS, 2011b, p. 819). Prova disso é que a Tradição nunca ousou colocá-los todos juntos, numa sequência, como temos as cartas do corpus paulino. Pelo contrário, respeitou-se a diferença de gênero ou tipo de literatura de cada escrito (BORING, 2016, v. II, p. 1124), embora, desde o séc. II d.C. tenham sido sempre associados um ao outro e continuam sendo chamados de escritos ou textos da tradição joanina.

Desde sua aceitação, o Evangelho foi colocado junto aos Evangelhos Sinóticos, ainda que com enorme diferença de estilo, simbologia, cronologia, geografia, vocabulário, teologia, etc.: tudo isso pode ser fruto das fontes e tradições usadas por João (FEUILLET, 1968, v. IV, p. 233) ${ }^{3}$. As Cartas, por sua vez, foram colocadas desde cedo junto com as cartas católicas; e o Apocalipse ficou separado dos demais textos, ocupando um lugar à parte no corpus do NT. Ao que tudo indica isso aconteceu bem cedo no cristianismo, pois "os escritos joaninos foram separados no início do processo de canonização" (BORING, 2016, v. II, p. 1124).

\footnotetext{
${ }^{2}$ Sobre a questão de serem endereçados para uma comunidade e aceitos por todos os cristãos, sugerimos a obra de Ong (2016, p. 101-123), tendo em vista a clara exposição do autor sobre a escrita, destinação e função do IV Evangelho e da Comunidade Joanina, que vivencia e pratica a fé no ressuscitado.

${ }^{3}$ Podemos conferir ainda Tuñi e Alegre (1999, v. 8, p. 11), Perkins (2011a, p. 732) e Harrington (2002, p. 592).
} 


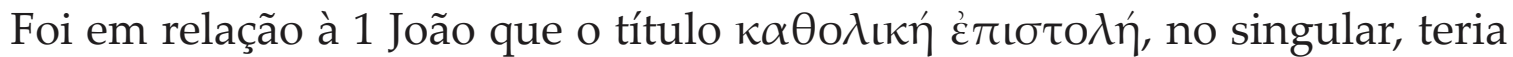
sido usado pela primeira vez, por Apolônio de Roma (BALLARINI, 1969, v. V/2, p. 285) $)^{4}$, um antimontanista, em 197 d.C. Dela teria se expandido para

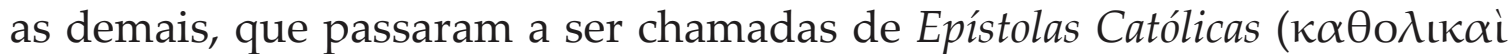

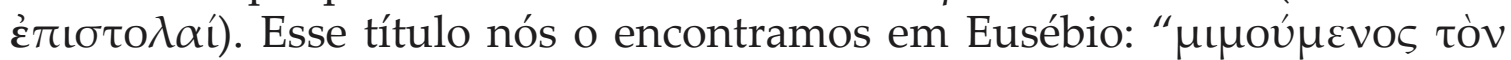

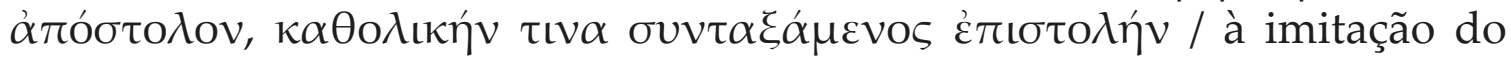
Apóstolo, compondo uma epístola católica" (EUSEBIO, 2008, p. 320; Hist. Ecles. V,18,5), e será adotado também por Jerônimo na tradução da Vulgata (CULLMANN, 2012, p. 69). Enfim, temos o Apocalipse, que é um livro único no cânon do NT e que, no arranjo, ficou para o final, após as epístolas católicas.

O número sete parece ter sido muito usado e valorizado pela Igreja Primitiva. Por exemplo, como sete são os deuterocanônicos do Antigo Testamento (Tobias, Judite, 1 e 2 Macabeus, Baruc, Eclesiástico, Sabedoria, além dos fragmentos de Dn 3,24-90, Dn 13-14 e Est 10,4-16,24), sete são os do NT (Hebreus, Tiago, 2 Pedro, 1 e 2 João, Judas e Apocalipse) $)^{5}$, assim chamados porque aceitos no cânon num momento posterior e com reservas (SACHI, 1995, p. 235), "cuja canonicidade muito se discutiu em algumas Igrejas" (MANNUCCI, 1999, p. 381). Além disso, vale a pena recordar que há sete cartas do Apocalipse (Ap 2,1-3,22); sete são as cartas de Paulo às Igrejas, se levarmos em conta que o mundo antigo tinha o segundo conjunto das cartas paulinas, também como sendo outras sete $(6$ de Paulo + Hebreus $=$ 7); ainda sete são as cartas católicas, etc., além de toda a simbologia do número sete no livro do Apocalipse.

Já os textos de atribuição joanina foram e permanecem sendo cinco, mesmo em corpora diferentes dentro do NT. Se não bastasse isso, eles são distintos entre si por uma certa homogeneidade e são representantes dos fundamentais gêneros literários neotestamentários: o evangélico, o epistolar e o apocalíptico. Em geral, os autores defendem que a obra joanina seja lida começando pelo evangelho, passando pelas cartas e terminando no Apocalipse. Mas há outros autores que defendem que a leitura deva ser iniciada pela primeira carta de João e, a partir dela, é que se deve percorrer todo o corpus joanino.

Entre as dificuldades para se estabelecer um parentesco entre o Evangelho e as Cartas com o Apocalipse, encontra-se o fato de que o gênero literário do Apocalipse é muito diverso. Tanto o Evangelho como as Cartas foram muito limitados no uso da linguagem ou simbologia apocalíptica, como as figuras "o último dia" e o "Filho do Homem" (TUÑI; ALEGRE, 1999, v. 8,

\footnotetext{
${ }^{4}$ Podemos conferir também Kümmel (1982, p. 508) e Harrington (2002, p. 574).

${ }^{5}$ Para uma melhor visualização da temática sobre as várias listas dos textos do Cânon do Novo Testamento, bem como sobre a questão de aceitação ou não de alguns dos livros que compreendem o corpus joanino, sugerimos a leitura da obra de Gonzaga (2019).
} 
p. 11). Além disso, o gênero de cada escrito também revela a autoridade que ele comporta: as Cartas, Atos e Apocalipse têm sua autoridade no ensinamento dos apóstolos, e os Evangelhos têm sua autoridade no ensinamento de Cristo (THEISSEN, 2007, p. 110).

O estilo linguístico é outro problema, pois, enquanto o Evangelho e as três Cartas têm um grego simples e popular, mas correto, o Apocalipse apresenta um com muitos solecismos, com "falhas ostensivas no uso da gramática grega" (TUÑI; ALEGRE, 1999, v. 8, p. 11). Por isso, vários autores julgaram que esse grego não pertencia à linguagem do autor, chamando-o de "pobre", inclusive no vocabulário (FEUILLET, 1968, v. IV, p. 233; CHIBERTI, 2003, p. 45). A diferença é tamanha que se torna até mesmo difícil sustentar que um mesmo autor tenha composto obras com linguagens e estilos tão diversos como o IV Evangelho e o Apocalipse.

O próprio uso antigotestamentário é algo bastante diferente entre as cinco obras do corpus joanino. Enquanto o Evangelho utiliza textos em geral e variados, o Apocalipse utiliza majoritariamente Daniel e Ezequiel, embora aluda também a outros, como Êxodo e Isaías. Ademais, o Evangelho não apela ao fato de visões ou de audições para falar da revelação. Por outro lado, o Apocalipse parece encontrar um forte apoio na história, enquanto isso não parece ser fundamental para o Evangelho e as Cartas. Esses últimos não negam a história, apenas "não a utilizam como veículo fundamental para fazer as suas apresentações teológicas" (TUÑI; ALEGRE, 1999, v.8, p. 11). Além disso, é oportuno observar que o Evangelho e o Apocalipse trazem muito mais referências ao AT que as três Cartas joaninas (BORING, 2016, v. II, p. 1121), que raramente o citam. Outro dado interessante é a forma de se referenciar ao AT: o Evangelho e o Apocalipse trazem citações explícitas, enquanto que nas Cartas apresentam apenas alusões ou ecos, trazidos de forma implícita.

Sendo diferentes em muitos dados, conteúdo, estilo, língua etc., fica realmente difícil sustentar uma autoria comum. Nem sequer o fato de o vidente do Apocalipse afirmar chamar-se "João" constitui um argumento forte que dê sustentação a favor de um parentesco entre os textos e seus autores. Fato é que a Tradição nem sempre foi unânime em aceitar a autoria joanina de todos esses cinco textos: 2-3 João e o Apocalipse encontraram dificuldades para entrar no Cânon do NT, justamente por causa de difícil sustentação de autenticidade apostólica, uma vez que, inicialmente, não tinham "o status autoritativo nos primeiros séculos" (PERKINS, 2011b, p. 818). Ao longo dos séculos, os cinco textos joaninos têm sido atribuídos e relacionados a diferentes possíveis autores, como o caso de "João, o discípulo amado" e "João, o presbítero", embora se deva pensar em uma escola ou comunidade Joanina, no tocante a uma mão redacional, em vista de alguns dados comuns entre as cartas, por exemplo (PERKINS, 2011b, p. 817; CHIBERTI, 2003, p. 129-130). 


\subsection{Comunidade joanina}

A comunidade joanina parece ter sido uma corrente do cristianismo bastante viva e devota ao Discípulo Amado, a ponto de recolher seus escritos e de seguir caminhando ao redor da pessoa de João e da mensagem dos escritos joaninos. Mas ela soube conviver contemporaneamente com a comunidade paulina, com sua escola e corrente. Isso é muito significativo, pois o paulinismo não conseguiu sufocar o mundo joanino ${ }^{6}$. Talvez tenha ajudado a isso o petrinismo muito forte na Igreja Primitiva, como lemos nos evangelhos e em outros escritos neotestamentários. Nesse sentido, a comunidade joanina pode ter sido influenciada também pela figura de Pedro, "como simbólico pastor de toda a Igreja" (BORING, 2016, v. II, p. 1122), por ser uma corrente um pouco diversa da paulina.

Entender a comunidade joanina ajuda inclusive a entender a questão da autoria dos escritos joaninos, especialmente das cartas (TAYLOR, 2011, p. 16). Ela, de fato, parece ter encarnado na figura do Discípulo Amado o próprio "idealismo joanino" (BROWN, 1982, p. 117)7, como sendo o "herói da comunidade joanina" (BROWN, 2003, p. 86), que viveu "fases diferentes" desde a adesão a Cristo até a escrita dos textos joaninos, inclusive na relação com os pagãos e os gnósticos (BROWN, 2003, p. 20-23), visto o "perigo do ecletismo religioso em que se encontravam os cristãos" (CHAPA; GONZÁLES-ALANO, 2018, p. 15) frente à religiosidade gnosticizante da época apostólica e pós-apostólica. Neste período, muitos buscavam movimentos de caráter dualista e algumas escolas gnósticas da época buscaram se apoiar no Evangelho de João para sustentar suas ideias e posições (BRUCE, 2013, p. 117), a exemplo do que veio à tona nas descobertas dos escritos da biblioteca gnóstica de Nag Hammadi (ARAUJO, 2015, p. 213-214). Isso demonstra que o "cristianismo joanino" ganhou força e sobreviveu dentro daquilo que alguns chamam de a "Grande Igreja" ou a Igreja dos "cristãos apostólicos" (BROWN, 2003, p. 84-92).

A "Grande Igreja" é a igreja presente a partir do séc. II, contando com os vários ramos do cristianismo, entre os quais os de contribuição joanina,

\footnotetext{
${ }^{6}$ A fim de se conhecer os vários cristianismos do período do NT, conferir o estudo apresentado por Bruce (2005). Esse trabalho nos proporciona uma ideia dos outros cristianismos fora do cristianismo paulino, que em termos de escritos foi superior aos demais, porém parece não ter sido a corrente dominante dentro da "Grande Igreja" ou das "Igrejas Apostólicas". Em termos de estruturação da vida comum, o petrinismo, o joanismo e o tiaguismo tiveram maior influência que o paulinismo, haja vista a citação do nome de Paulo e de Pedro nos escritos do NT. Paulo aparece de forma abundante em suas cartas, especialmente nas saudações, em Atos dos Apóstolos e em 2Pd 3,15. Pedro está de forma predominante nos Evangelhos, em Atos dos Apóstolos, em Gl 2,7.8.14 e na saudação das duas cartas a ele atribuídas. A mesma coisa poderíamos dizer de João (Evangelhos, Atos, Gl 2,9; Ap 1,1.4.9; 22,8) e de Tiago (Evangelhos, Atos, Tg 1,1; Jd 1; Gl 1,19; 2,9.12), que aparecem mais nos Evangelhos e no livro dos Atos dos Apóstolos, e pouco nas cartas e no livro do Apocalipse.

${ }^{7}$ Conferir ainda Brown (2003, p. 32), Chapa e Gonzáles-Alano (2018, p. 17).
} 
inclusive em termos de escritos que a Escola Joanina conservou e foi transmitindo às gerações futuras, até que ganhasse status de Escritura Sagrada dentro do Cânon do NT. Mesmo que seus livros tenham sido dispostos separadamente em seus vários corpora, não ganhando um único corpus, como os textos do corpus paulino, adquiriram força de regula veritatis fidei para a vida dos cristãos e entraram para o cânon bíblico. Isso se justifica pelo fato de que os cinco textos do corpus joanino contam com gêneros diversos de literatura (evangelho, carta e apocalipse) enquanto os textos do paulino contam com um único gênero de literatura (carta/ epístola). Mesmo que alguém incluísse a carta aos Hebreus como de atribuição paulina, o que já não é mais aceito (GONZAGA, 2017b, p. 22), isso nada alteraria, pois ela também poderia se encaixar no gênero carta/ epístola, tida como "um sermão exortativo, rico em exposição teológica e exegese alexandrina do AT" (FITZMYER, 2011, p. 399). Se podemos falar de Escola Joanina e Escola Paulina, o mesmo não é possível em relação a Pedro ou a Tiago, pois não existiram uma "Escola Petrina" e uma "Escola Tiaguina", uma vez que:

Pedro e Tiago, como pseudônimos, sinalizam, ao invés, correntes universais no cristianismo primitivo. Pedro representa todo o cristianismo. Tiago e Judas o judeu cristianismo. E nas cartas que lhes são atribuídas trata-se sempre de corrigir Paulo, ou de corrigir o paulinismo depois dele (THEISSEN, 2007, p. 105).

No que tange à figura de João, o Presbitero, segundo Eusébio de Cesareia, em sua obra História Eclesiástica $(3,39.4)$, poderíamos dizer que, de fato, existiu um personagem na Igreja antiga. Ele também era conhecido com o nome João, mas não era o Apóstolo e Evangelista, e sim um outro João, cognominado o Presbítero:

No entanto, se vinha a determinado lugar algum dos companheiros dos presbíteros, informava-me sobre as palavras dos presbíteros: o que dissera André ou Pedro, ou Filipe, ou Tomé, ou Tiago, ou João, ou Mateus, ou qualquer outro dos discípulos do Senhor; o que dizem Aristion e o presbítero João, discípulos do Senhor. Não pensava serem tão úteis os ditos provenientes dos livros quanto o que deriva de uma palavra viva (EUSEBIO, 2008, p. 191) ${ }^{8}$.

Essa mesma notícia é confirmada, mais tarde, pelo Concílio Romano (382 d.C.) e pelo Decreto Gelasiano (392-396 d.C.). Ao tratarem dos textos joaninos, dizem que teríamos autorias diversas para os escritos deste corpus, afirmando a autoria para cada um. Eles citam exatamente João, o Presbitero, para 2-3 João, tal como visto em Eusébio de Cesaréia, em seu

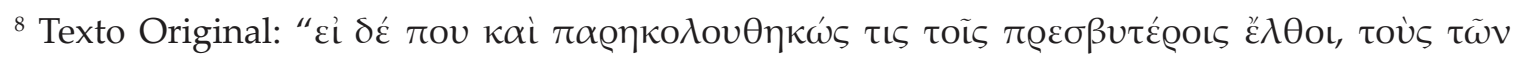

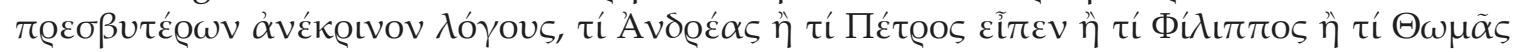

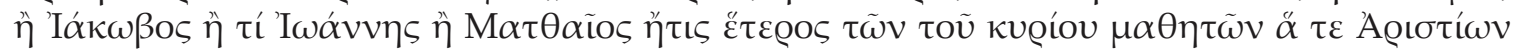

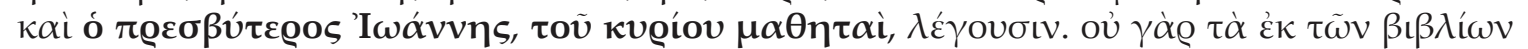

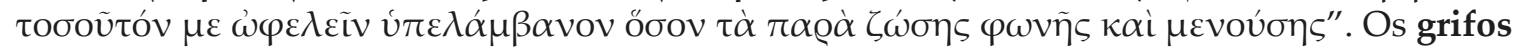
colocados aqui e na tradução são nossos.
} 
escrito datado de 324 d.C. Portanto, uma informação ao início e outra ao final do séc. IV:

secundum Iohannem liber unus (Euangelium) / segundo João, um livro (Evangelho); Item apocalypsis Iohannis liber unus / também o Apocalipse de João, um livro / Iohannis apostoli epistula uma / do apóstolo João uma carta / alterius Iohannis presbyteri epistulae duae / do outro João, o presbítero, duas cartas (GONZAGA, 2019, p. 110).

Em meio a tantas discussões entre os Padres da Igreja, os Sínodos e os primeiros Concílios, a Igreja Primitiva só foi chegar a uma visão unificada de que o Apóstolo João, filho de Zebedeu, e o Presbítero das cartas eram o mesmo somente depois de muitas discussões e debates, fechando o cânon do NT no final do séc. IV (GONZAGA, 2019, p. 13-18). Segundo Boring (2016, v. II, p. 1123), este foi o momento em que se deu a atribuição definitiva a João, o evangelista. Mas isso nunca foi consenso, tanto que a problemática foi ressuscitada pelos Pais da Reforma, no séc. XVI, trazendo novamente à tona toda a problemática dos deuterocanônicos do AT e do NT, dentre os quais se encontram três textos joaninos, a saber: 2-3 João e Apocalipse, que entraram tardiamente e com dificuldades no cânon do NT, enquanto os protocanônicos entraram com maior facilidade ${ }^{9}$, sem "nenhuma discussão" (MANNUCCI, 1999, p. 380-381). Esse processo se deu obedecendo aos quatro critérios para a formação do Cânon do NT ou notae canonicitatis, a saber: a) apostolicidade e pregação apostólica; b) regra

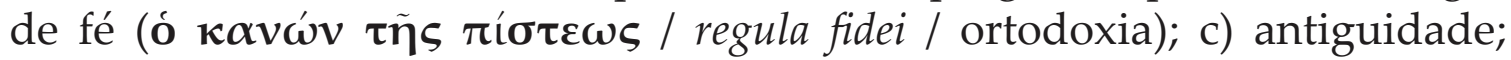
d) uso litúrgico e adaptabilidade nas igrejas locais (GONZAGA, 2017a, p. 429-432) ${ }^{10}$. A tentativa foi aquela de se chegar a um cânon que contivesse

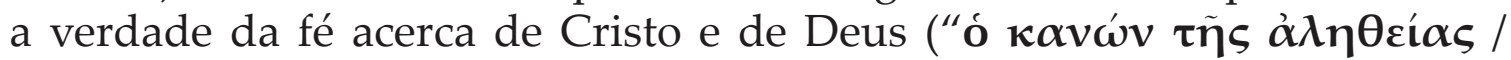
regula veritatis / regra da verdade) (METZGER, 2009, p. 252).

Vários foram os problemas levantados, por exemplo, acerca do livro do Apocalipse, que foi um documento controverso desde o início do cristianismo. Aliás, alguns autores afirmam que ele é um dos livros mais enigmáticos e controvertidos do NT, elogiado por uns e criticado por outros (TUÑI; ALEGRE, 1999, v. 8, p. 191). Para entendermos a sua recusa e omissão pelos Orientais, temos um paradigma que é Cirilo de Jerusalém, que recusa o Apocalipse devido ao uso excessivo que os montanistas fazem dele em seus cultos e celebrações (GONZAGA, 2019, p. 81). Aqui vale ressaltar que, enquanto o Oriente tinha dificuldades para aceitar o Apocalipse, o

\footnotetext{
${ }^{9}$ Já nos primórdios do cristianismo, houve autores que, ao invés de falar de "livros protocanônicos" e "livros deuterocanônicos", pois tal nomenclatura é do séc. XVI d.C., falaram de "livros medulares" (Evangelhos, Atos, Cartas Paulinas, 1 Pedro, 1 João) e de "livros marginais" (Hebreus, Tiago, 2 Pedro, 2-3 João, Judas e Apocalipse). Sugerimos conferir a temática igualmente em McDonald (2013, p. 204).

${ }^{10}$ Podemos conferir também Gonzaga (2019, p. 413-416), Bruce (2013, p. 231-244) e Metzger (2009, p. 251-257).
} 
Ocidente tinha dificuldades em aceitar a Carta aos Hebreus. Isso só será resolvido com o Concílio de Roma (382 d.C.) (GONZAGA, 2019, p. 105), com o Concílio de Hipona (393 d.C.) (GONZAGA, 2019, p. 153) e com o III Concílio de Cartago (397 d.C.) (GONZAGA, 2019, p. 162).

Gaio, presbítero de Roma (210 d.C.), escreveu que o livro do Apocalipse tinha sido escrito pelo herético Cerinto; por sua vez, Dionísio, de Alexandria (250 d.C.), afirmou que o grego desde livro era muito diferente do Evangelho de João; por isso, ele não podia ser do mesmo autor e, portanto, ele não era apostólico (BORING, 2016, v. II, p. 1123-1124). Isso acirrou ainda mais os ânimos dos Padres Orientais, que já teciam muitas dúvidas e rejeitavam o livro Apocalipse. Somente quando este livro foi aceito como Escritura inspirada, é que o autor foi identificado como o Apóstolo João (BORING, 2016, v. II, p. 1124).

O Evangelho de João foi considerado inicialmente suspeito pela Igreja nascente, por ser acusado de dualismo, de uso de conceitos e de linguagem do gnosticismo, corrente do cristianismo antigo que produziu vasta e ampla literatura ligada ao mundo religioso de então, mas que também usou e interpretou "os livros recebidos pela Igreja, interpretando-os a seu modo" (METZGER, 2009, p. 78). Exatamente por isso o Evangelho de João foi adotado pelos círculos cristãos gnósticos e muito usado sobretudo durante o séc. II, suscitando sempre e cada vez mais um "um vivo interesse" (MAGRI, 2005, p. 125). Assim como para o Apocalipse, apenas quando foi aceito como Escritura inspirada é que ele recebeu autoria Joanina apostólica: João, o Evangelista.

\subsection{Provável datação e arranjo}

No que diz respeito à datação ${ }^{11}$, não é fácil determinar. Melhor falar de período ou de década dos escritos joaninos, visto que podemos situar todos no final do primeiro século do cristianismo, quando também podemos colocar a morte de João, o apóstolo. Perkins, em seu texto sobre "as epístolas joaninas", afirma que "se o Evangelho se origina cerca de 90 d.C., as epístolas representariam a situação das comunidades joaninas em cerca de 100 d.C." (2011b, p. 818) ${ }^{12}$. De todas as maneiras, poderíamos dizer que uma data provável é na última década do séc. I d.C. ou na virada para o séc. II d.C. (BORING, 2016, v. II, p. 1120), encontrando-se "entre as últimas produções do Novo Testamento" (COTHENET et al., 1988, p. 9).

\footnotetext{
${ }^{11}$ Sugerimos a leitura da obra de Porter (2016, p. 11-29), na qual o autor apresenta as mais recentes pesquisas sobre autoria, data, fontes, tradições, etc., a respeito do IV Evangelho.

${ }^{12}$ Essa mesma ideia é defendida pela maioria dos autores, que falam de uma tradição préjoanina e depois da redação do Evangelho, das três Cartas e do Apocalipse, nessa ordem, por mãos diferentes na escrita desses cinco escritos atribuídos a João (BROWN; COLLINS, 2011, p. 931,936; TAYLOR, 2011, p. 16,26).
} 
No que tange ao arranjo, os cinco escritos do corpus johannicum foram separados e colocados em grupos diferentes. O Evangelho de João foi posto no cânon com os Evangelhos Sinóticos. As Cartas Joaninas foram colocadas com as Católicas ${ }^{13}$, deixando João ao lado da figura dos Apóstolos Tiago e Pedro (GOSWELL, 2018, p. 718), seguido de Judas, quase que querendo realçar a figura dos três pilares da Igreja Primitiva (DAVIDS, 2009, p. 403-416). Já o Apocalipse ficou sozinho, no final do cânon do NT. Para se chegar a esse ponto, foi necessário um processo realmente longo e árduo. É preciso ter presente os critérios para se admitir se um texto podia ser ou não normativo para a vida cristã, sendo norma e regra de vida (MANNUCCI, 1999, p. 380), sempre na tentativa de se reconhecer as autênticas testemunhas da fé apostólica e não se separar delas.

Marcião foi o único escritor antigo que recusou todos os textos do corpus joanino, apresentando um cânon mutilado do NT. Aliás, ele recusa todo AT e parte dos escritos neotestamentários, aceitando apenas o Evangelho de Lucas e 10 cartas paulinas, mesmo assim, mutilados dos textos que ele julgou favoráveis aos judeus (BRUCE, 2013, p. 122-124). Ele também defendeu que o Deus "vingativo" do AT e o Deus "misericordioso" do NT não poderiam ser, de forma alguma, o mesmo, por isso não tinha como aceitar os livros veterotestamentários (METZGER, 2009, p. 91). Enquanto isso, os Padres da Igreja, Orientais e Ocidentais, os Sínodos e os Concílios antigos aceitaram os 4 Evangelhos, as cartas paulinas, as cartas católicas e o Apocalipse. É claro que temos quem aceitou mais e quem aceitou menos textos dos atuais que temos no cânon netotestamentário, inclusive entre os textos mais disputados do NT, que não entraram em seu cânon (GONZAGA, 2019, p. 393).

Enquanto a grande maioria coloca João como ocupando o quarto lugar no corpus dos Evangelhos (como temos na ordem do cânon do NT: Mateus, Marcos, Lucas e João), poucos são os que divergem disso. Por exemplo: a) Cânon de Cheltenham/Mommsen traz a ordem: Mateus, Marcos, João e Lucas; b) Cânon Claromontano: Mateus, João, Marcos e Lucas; c) João Crisóstomo: João, Mateus, Lucas e Marcos.

Ainda no que diz respeito ao arranjo do cânon joanino no corpus do NT, o que observamos é que, quando o livro do Apocalipse é citado, em sua grande maioria entre os Padres Ocidentais, ele vem quase sempre em último lugar, precedido dos Evangelhos (inclusive João), de Atos dos Apóstolos, da Cartas Paulinas e Católicas.

No que tange às três cartas joaninas, o arranjo é mais complexo, pois elas são colocadas junto com as católicas, mas nem sempre se respeita a mes-

\footnotetext{
${ }^{13}$ Sobre a disposição das cartas joaninas dentro do epistolário no corpus cartas católicas e no corpus do inteiro Novo Testamento, sugerimos a leitura do texto de Manson (1947, p. 32-33), no qual o autor trata toda essa temática de forma abrangente.
} 
ma ordem e muito menos se conta sempre com a aceitação das três. A ordem que temos no cânon das cartas Católicas dentro do cânon do NT hoje é: Tiago, 1 e 2 de Pedro, 1, 2 e 3 de João, Judas, ocupando, portanto, o terceiro lugar entre as figuras dos apóstolos, após Tiago e Pedro e antes de Judas (NESTLE-ALAND, 2012). Esses escritos são pequenos em seu tamanho, mas grandes em seu conteúdo, de grande "densidade espiritual e papel na vida cristã" (COTHENET et al., 1988, p. 9). Têm uma riqueza teológica que não encontramos nos demais corpora neotestamentários, e as cartas joaninas constituem verdadeiras joias da inteira Sagrada Escritura (FEUILLET, 1968, v. IV, p. 226) ${ }^{14}$, embora muito breves, sobretudo a segunda e a terceira. Como bem expressa Boring:

Os escritos Joaninos representam todo o Novo Testamento: expansão geográfica da palestina e o restante do mundo, expansão teológica, expansão cultural e sociológica. As tradições incorporadas tanto no Apocalipse como no Evangelho fazem a transição da Judeia para Éfeso (2016, v. II, p. 1121).

\section{Literatura Apócrifa atribuída a João}

Uma palavra precisa ser dada ainda à literatura apócrifa atribuída a João, o Apóstolo e Evangelista, chamada também de Apócrifos de João, surgidos já desde o séc. II. São eles: O Apócrifo de João (100-150 d.C.); Os Atos de João (c. 150 d.C.); Restos dos Diálogos entre João e Jesus (séc. II); A sorte de João, o teólogo, e de Maria (séc. IV); O Livro de São João, o evangelista e teólogo (séc. IV); O Livro Secreto de João (séc. IV); A Revelação de São João, o teólogo (séc. IV); O Livro do Pseudo João (400-450 d.C.); Paixão de João (séc. V); Atos do Santo Apóstolo e Evangelista João (séc. V-VI); Os Atos de João e do Pseudo Prócor (séc. V-VI); História Siríaca de João, o Filho de Zebedeu, Apóstolo e Evangelista (séc. V-VI); Tratado de São João, o Teólogo, sobre a passagem da Santa Mãe de Deus (séc. VI); O Livro de João, Arcebispo de Tessalônica, sobre a Dormitio Mariae (c. 630 d.C.); Homilia do Metropolita João, sobre a Assunção de Maria (época incerta); A Lenda Siro-Etiópica e o Pseudo João (medieval); Carta de Inácio a João (medieval $^{15}$. Todos esses escritos, e tantos outros atribuídos aos demais apóstolos, foram surgindo com o passar do tempo, sobretudo após a morte das testemunhas oculares, na tentativa da preservação da memória dos atos e das palavras do mestre, bem como das interpretações e correntes

\footnotetext{
${ }^{14}$ Conferir ainda O'Callaghan (2000, p. 65) e Davids (2009, p. 403-416).

${ }^{15}$ Os textos e explanações desses apócrifos atribuídos a João, o apóstolo, evangelista e teólogo, podem ser encontrados nos quatro volumes da obra sobre Apócrifos do Novo Testamento de Erbetta (1998, v. II; 1999, v. I/1; 2003, v. I/2; 2015, v. III); alguns deles foram traduzidos e publicados em português, os quais podemos encontrar nas obras de Proença (2010, v. 1; 2012, v. 2).
} 
que foram surgindo dentro do cristianismo (BROWN; COLLINS, 2011, p. 925-926).

Toda essa literatura apócrifa atribuída a João, apóstolo e evangelista, revela-nos a grandeza e a envergadura de sua figura entre os apóstolos. Aliás, ele foi um dos mais proeminentes, estando presente em vários momentos da vida de Cristo e da Igreja nascente. Era um dos Doze, escolhido pelo próprio Cristo para formar o círculo mais estreito de seus apóstolos e amigos (Mt 10,2; Mc 3,17; Lc 6,14), e, mesmo quando se reuniram em Pentecostes, lá estava ele entre os demais apóstolos (At 1,13). Recordemos ainda, por exemplo, que o João era filho de Zebedeu (Mt 4,21; Mc 1,20), irmão de Tiago, o maior (Lc 5,10), discípulo de João Batista (Jo 1,35-41), sendo um dos primeiros a tudo deixar e seguir o Cristo, Mestre e Senhor. Ele é tido como sendo o Discípulo Amado que, na última ceia, reclina a cabeça ao peito de Jesus (Jo 13,23-25). É uma das testemunhas da transfiguração (Mt 17,1; Mc 9,2; Lc 9,28) e da agonia do Senhor (Mc 14,33; Mt $26,37)$, além de estar presente aos pés da cruz e ser a quem Jesus confia sua mãe (Jo 19,26-27). Após a cura da hemorroíssa e a ressurreição da filha de Jairo, ele é um dos três que Jesus permite que o siga e entre na casa (Mc 5,37; Lc 8,51). Junto com Pedro, entra no sepulcro, o vê vazio e acredita na ressurreição do Senhor (Jo 20,1-9).

João é um dos três apóstolos que Paulo diz encontrar em Jerusalém (Gl $2,9)$. Ele é chamado de "o divino teólogo", "o teólogo por excelência" (ZARAGOZA, 2017, p. 64), "o santo Teólogo" ou o "mais profundo dos teólogos" (COTHENET et al., 1988, p. 9), por entrar e aprofundar-se no mistério de Verbo Encarnado (verbum incarnatum), o Filho de Deus feito homem (Jo 1,1-18), por afirmar e ensinar que "Deus é amor" (1Jo 4,8). Ele é a testemunha ocular por excelência: aquele que vê, crê e dá testemunho e seu testemunho é verdadeiro (Jo 19,35; 21,24). É quem sobe com Pedro ao Templo, após a ressurreição, e está presente na cura do "homem coxo", diante da Porta Formosa (At 3,1-3.8.11). Após esse milagre, é levado diante dos sacerdotes, dos guardas do Templo e dos saduceus e é preso (At 4,1-3.7.18.21.23). Ele é enviado junto com Pedro desde Jerusalém para a Samaria, após ouvir falar que lá o povo tinha acolhido a Palavra de Deus (At 8,14.17). Enfim, segundo Ap 1,9-10, estando exilado na Ilha de Patmos, na qual teve as suas visões, João foi arrebatado em êxtase no dia do Senhor.

\section{$3 \mathrm{O}$ corpus joanino no arranjo dos catálogos antigos}

No período nascedouro e antigo do cristianismo, alguns livros tanto do AT (Tobias, Judite, 1 e 2 Macabeus, Baruc, Eclesiástico, Sabedoria, além dos fragmentos de Dn 3,24-90, Dn 13-14 e Est 10,4-16,24) como do NT (Hebreus, Tiago, 2 Pedro, 1 e 2 João, Judas e Apocalipse) encontraram dificuldades de 
aceitação a fim de entrar no cânon das Sagradas Escrituras. Isso levou-os a ganhar, mais tarde, da parte de Sixto de Siena (1566), o nome de deuterocanônicos do AT e do NT (GONZAGA, 2019, p. 317-322). Mas, mesmo quando esses livros foram aceitos, a introdução deles no arranjo do cânon bíblico não foi uma tarefa tão simples em termos de se encontrar qual lugar cada um tomaria e em qual corpus cada um entraria. Como o nosso interesse aqui são os livros dos corpora neotestamentários, e, em especial, do corpus joanino, então iremos indicar onde esses livros de atribuição joanina entrariam, segundo os testemunhos que temos, sempre tendo presente que o arranjo sofreu várias sugestões e a migração de lugar reflete o valor que era dado aos escritos neotestamentários ${ }^{16}$.

O que vemos entre os vários Padres da Igreja (Orientais e Ocidentais), Sínodos e Concílios é que realmente existe uma diferença na aceitação de cada livro no corpus do cânon e na concepção de onde cada um entraria, ou seja, a qual grupo cada obra pertenceria. Assim, conseguimos identificar o arranjo do cânon não apenas de cada corpus dentro do NT, mas também do corpus do inteiro NT. É justamente isso que queremos indicar aqui abaixo, visto que nos ajuda a entender o valor que cada obra foi obtendo ao longo do processo de canonização, até que chegássemos a ter os atuais arranjos e a estrutura do cânon de cada corpus e de todo o NT, passando por todas as discussões entre ocidentais e orientais. Enfim, indicamos os três corpora neotestamentários onde há algum texto joanino, menos o corpus paulinum, atribuído a um só autor. Nesse sentido, temos:

\section{$3.1 O$ corpus do Novo Testamento ${ }^{17}$}

No que diz respeito ao cânon do corpus do NT como um todo (GONZAGA, 2019, p. 404-406), o que percebemos é uma aceitação maior da ordem dos livros como o temos em nossas Bíblias ainda hoje. Entre orientais e ocidentais, isso não foi tão pacífico assim. Enquanto os ocidentais defendiam a ordem superior das cartas paulinas, inclusive por antiguidade e valor, os orientais defendiam a primazia das cartas católicas, tendo em vista a

\footnotetext{
${ }^{16}$ Sobre a ordem e o arranjo dos livros no cânon do NT e como se deram, indicamos a leitura do texto de Goswell (2010, p. 225-241), por sua clareza na exposição, inclusive elucidando a diferença entre os orientais e os ocidentais na aceitação e na formação do cânon bíblico neotestamentário ao longo dos primeiros séculos do cristianismo, até que se chegasse a uma conclusão comum, no final do séc. IV d.C.

${ }^{17}$ Como fonte e subsídio desses arranjos aqui apresentados, indicamos tanto o artigo sobre o Corpus Paulinum (GONZAGA, 2017b, p. 31-35) como o Compêndio do Cânon (GONZAGA, 2019, p. 405-409). Todas as duas obras são de nossa autoria. Essas "tabelas" aqui reproduzidas são indicativas e, acadêmica e didaticamente, constituem, além de um excelente material a ser usado em salas de aula, uma grande contribuição para estudos e pesquisas de quem entrar em contato com o artigo e quiser se aprofundar na temática, quem sabe, com futuras dissertações e teses na área. O leitor perceberá também que há uma pequena diferença na aglomeração dos autores, concílios e sínodos citados, tendo em vista o objetivo, mas é o mesmo material, sem, é obvio, o arranjo do corpus paulinum, por ser uma literatura única.
} 
precedência da personalidade dos apóstolos do grupo do Doze, visto que Paulo não fazia parte deste grupo original dos Doze Apóstolos. Porém, a partir do final do séc. IV d.C., isso foi se tornando cada vez mais pacífico e as cartas paulinas foram colocadas logo após Evangelhos e Atos e seguidas pelas cartas católicas e Apocalipse, como encontramos nos catálogos antigos (BROWN; COLLINS, 2011, p. 910). A seguir, indicamos, por primeiro, os que trazem todos os corpora na ordem que temos em nossas Bíblias hoje; em seguida, trazemos os que apresentam uma ordem diferente; depois, os que não citam o Apocalipse; e, por fim, Marcião, que recusou todos os livros do corpus joanino, aceitando apenas o Evangelho de Lucas e 10 cartas paulinas (HAAG, 1971, v. I/2, p. 142).

Neste primeiro momento, não indicamos se todas as listas trazem todas as cartas joaninas dentro do corpus das católicas. Isso deve ser conferido no corpus das cartas católicas abaixo. Indicamos quem aceita e onde são colocados Atos dos Apóstolos e Apocalipse apenas aqui no cânon geral do NT. Não criamos subgrupos para eles, pois são livros "únicos" do gênero de literatura dentro desse corpus. Recordando Collins (2011, p. 835), poderíamos dizer que Atos e Apocalipse são livros singulares dentro do NT. Basta vê-los no arranjo geral do corpus neotestamentário. Para os demais corpora sim, pois contam com várias obras em cada corpus e com disposição diferente em cada autor. Enfim, também podemos constatar que, no período Antigo, houve uma pluralidade e uma divergência de visão muito grandes sobre o arranjo geral dos corpora neotestamentários, no que diz respeito à ordem de cada corpus, visto que cada um o concebia de uma forma, segundo seus critérios de valoração dos livros e autores.

a) Cânon Muratoriano; Irineu; Clemente de Alexandria; Tertuliano; Cipriano; Dídimo (o Cego); III Concílio de Cartago (Norte da África); Eusébio de Cesareia; Códice Sinaítico; Vulgata, versão Copta, versão Etiópica; Anfilóquio; Rufino; Hugo de São Vitor: Evangelhos, Atos, Paulo, Católicas e Apocalipse;

b) Jerônimo e Epifânio: Evangelhos, Paulo, Atos, Católicas e Apocalipse;

c) Agostinho; Inocente I; Cassiodoro; Isidoro e João de Salisbury: Evangelhos, Paulo, Católicas, Atos e Apocalipse;

d) Códice Alexandrino; Atanásio; Synopsis Scripturae Sacrae; Leôncio e João Damasceno: Evangelhos, Atos, Católicas, Paulo e Apocalipse;

e) Cânon de Cheltenham/Mommsen: Evangelhos, Paulo, Atos, Apocalipse e Católicas;

f) Concílio Romano e Decreto Gelasiano: Evangelhos, Atos, Paulo, Apocalipse e Católicas;

g) Junílio: Evangelhos, Atos, Apocalipse, Paulo e Católicas. 
h) Irineu e Orígenes: Evangelhos, Apocalipse, Católicas e Paulo;

i) Códice Claromontano: Evangelhos, Paulo, Católicas, Apocalipse e Atos;

j) Cânon Apostólico: Evangelhos, Paulo, Católicas e Atos (não traz o Apocalipse);

1) Filastro; Nicéforo; Sessenta; Livros Versão Peshita: Evangelhos, Atos, Paulo e Católicas (não trazem o Apocalipse);

m) Gregório de Naziano e Versão Georgiana: Evangelhos, Atos, Paulo e Católicas (não trazem o Apocalipse);

n) Syriaca e Armena: Evangelhos, Atos, Paulo e Católicas (não trazem o Apocalipse);

o) Cirilo de Jerusalém; Anônimo in notis; Concílio de Laodiceia e Códice Vaticano: Evangelhos, Atos, Católicas e Paulo (não trazem o Apocalipse);

p) Concílio de Antioquia: Evangelhos, Católicas e Paulo (não traz o Apocalipse);

q) João Crisóstomo: Paulo, Evangelhos, Atos e Católicas (não traz o Apocalipse)

r) Marcião: Lucas e Paulo (recusou todo o corpus joanino).

\subsection{No corpus dos Evangelhos}

Como podemos constatar aqui, no que tange ao corpus evangeliorum (GONZAGA, 2019, p. 406), a maioria dos Padres da Igreja, Orientais e Ocidentais, os Sínodos e os Concílios concordam com o arranjo em que João permanece após os três sinóticos. Inclusive, conserva a estrutura que temos no Cânon Bíblico do NT: Mateus, Marcos, Lucas e João. Os que trazem um arranjo diferente são apenas os cânones de Cheltenham/ Mommsen, o Claromontano, João Crisóstomo e Marcião, que recusou todo o corpus joanino.

Seguindo o raciocínio de que a ordem indica o grau de valor para cada autor, o que percebemos é que, enquanto para João Crisóstomo (404 d.C.) o Evangelho de João teria um valor muito grande, para Marcião (144 d.C.) não deveria sequer ser aceito como canônico. Taciano (170 d.C.), por sua vez, tomou como base o Evangelho de João como espinha dorsal para construir o texto da Diatessaron (ÁLVAREZ MAESTRO, 2002; ARAMAS, 2015). Ao Evangelho de João, Taciano acrescentou os dados dos Sinóticos, a fim de completar o que vários autores chamam de "a primeira biografia de Cristo" ou a "harmonia das quatro partes (BRUCE, 2013, p. 116). A Diatessaron também é chamada de "harmonia revisada" (PETERSEN, 2005, p. 90), segundo os dados dos quatro evangelhos. Para tal empreitada, o Evangelho de João serviu como "moldura" (BRUCE, 2013, p. 116), a fim 
de ser fortalecido e enriquecido com os demais dados da vida de Cristo, apresentados pelos Evangelhos de Mateus, Marcos e Lucas. Esse texto foi aceito e usado até o séc. V d.C. pela Igreja Siríaca (BROWN; COLLINS, 2011, p. 931), embora ela tivesse ressalvas às cartas católicas e ao Apocalipse, criando, com isso, problemas para a aceitação dos demais textos do corpus joanino.

a) Cânon Muratoriano; Orígenes; Eusébio; Cirilo; Irineu; Clemente de Alexandria; Tertuliano; Cipriano; Dídimo (o Cego); Concílio de Laodiceia; Atanásio; Gregório de Nazianzo; Anfilóquio; Cânon Apostólico; Concílio de Antioquia; Concílio Romano; Decreto Gelasiano; Epifânio; Jerônimo; Agostinho; III Concílio de Cartago; Rufino; Inocente I; Filastro; Códice Vaticano; Códice Sinaítico; Códice Alexandrino; Synopsis Scripturae Sacrae; Patriarca Nicéforo; Junílio; Cassiodoro; Isidoro; Leôncio; Sessenta Livros; João Damasceno; Hugo de São Vitor; João de Salisbury; Anônimo in notis; versões Peshita/Syriaca; Vulgata; Armena; Copta; Etiópica e Georgiana: Mateus, Marcos, Lucas e João.

b) Cânon de Cheltenham/Mommsen: Mateus, Marcos, João e Lucas.

c) Cânon Claromontano: Mateus, João, Marcos e Lucas.

d) João Crisóstomo: João, Mateus, Lucas e Marcos.

e) Marcião: Lucas (recusou todo o corpus joanino)

\subsection{No corpus das Cartas Católicas}

No que diz respeito ao corpus catholicum (GONZAGA, 2019, p. 408-409; GONZAGA, 2017a, p. 421-444), o que constatamos é que, desde a Antiguidade, este é um corpus que enfrentou muita divergência e dificuldades para a aceitação de seus sete livros. Aliás, este é o corpus onde temos, inclusive, escassez de estudos e que deu vários problemas ao longo da história do cânon. No período da Reforma, novamente com recusa de alguns de seus textos, apresentou-se novamente um cânon mutilado, ou seja, faltando alguns livros neotestamentários, a exemplo de Marcião (144 d.C.).

Enquanto as cartas protopaulinas, as deuteropaulinas e as pastorais são distinguidas pelo nome dos destinatários, as católicas são identificadas e distinguidas pelo nome do escritor a quem são atribuídas textual ou tradicionalmente (FITZMYER, 2011, p. 405); outro dado é a unidade do corpus paulino ao redor de seu autor (BALLARINI, 1969, v. V/2, p. 285) ${ }^{18}$. A carta aos Hebreus, porém, encontra problemas para entrar no conjunto das católicas, visto que se identifica pelos destinatários e não pelo autor,

${ }^{18}$ A fim de se ter uma melhor ideia sobre o corpus paulinum, indicamos a leitura do artigo de Gonzaga (2017b, p. 19-41). 
a exemplo das paulinas. Esta é uma temática que precisa ser mais bem estudada e definida. Uma possibilidade seria que a carta aos Hebreus ficasse sozinha no Cânon do NT, como temos, por exemplo, o livro do Apocalipse.

Olhando para os vários autores, percebemos que a maioria aceita todas as três cartas joaninas, com diferenças na ordem do arranjo conforme temos hoje no cânon do NT, ou seja, para alguns, a ordem das sete cartas seria diferente. Pelo que podemos ver, em relação à diferença, esta se dá entre orientais e ocidentais. O Oriente deu precedência ao arranjo que temos hoje: Tiago, 1 Pedro, 2 Pedro, 1 João, 2 João, 3 João e Judas (WESTCOTT; HORT, 1906), talvez seguindo a ordem dos nomes dos Apóstolos conforme lemos em Gl 2,9 (FITZMYER, 2011, p. 405): "I $\alpha \alpha \kappa \omega \beta о \varsigma ~ \kappa \alpha i ̀ ~ K \eta \varphi \tilde{~} \varsigma$

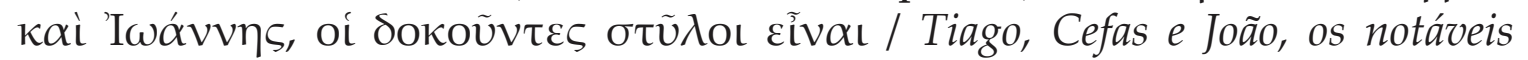
tidos como colunas", deixando, é óbvio, a carta de Judas para o fim. O Ocidente, por sua vez, parece ter visto o grupo das cartas católicas como um apêndice das paulinas e, por isso, dispôs as mesmas após as cartas paulinas, dando, porém, "preferência a Pedro sobre Tiago, certamente por causa da posição que Pedro ocupa no Colégio Apostólico" (BALLARINI, 1969 , v. V/2, p. 288). Como podemos conferir a seguir, a única carta que dificilmente é alterada na ordem é de Judas, que quase sempre ocupa o último lugar. Exatamente por estarem atribuídas a quatro figuras do colégio apostólico, alguns também as chamaram de "cartas apostólicas" (SACHI, 1995, p. 235). As demais sofrem constantes alterações, dependendo do cânon de cada autor, mas este é um fenômeno que se dá especialmente entre os ocidentais.

a) Cirilo de Jerusalém; Concílio de Laodiceia; Concílio de Antioquia; Atanásio; Gregório de Nazianzo; Epifânio; Jerônimo; Synopsis Scripturae Sacrae; Patriarca Nicéforo; Leôncio; Sessenta Livros; João Damasceno; Hugo de São Vitor; Anônimo in notis; Códice Sinaítico; Códice Alexandrino; Códice Vaticano; versões Vulgata, Armena e Georgiana: Tiago, 1 e 2 de Pedro, 1, 2 e 3 de João, Judas.

b) Concílio de Cartago: 1 e 2 de Pedro, 1, 2 e 3 de João, Tiago e Judas.

c) Concílio Romano; Decreto Gelasiano e Cânon Claromontano: 1 e 2 de Pedro, Tiago, 1, 2 e 3 de João, Judas.

d) Agostinho e Rufino: 1 e 2 de Pedro, Tiago, Judas, 1, 2 e 3 de João.

e) Inocêncio I; Isidoro: 1, 2 e 3 de João, 1 e 2 de Pedro, Judas, Tiago.

f) Filastro, versões Copta e Eiópica: 1 e 2 de Pedro, 1, 2 e 3 de João, Judas, Tiago.

g) Cânon Muratoriano: Judas, duas de João (não cita a terceira).

h) Orígenes: Pedro, João (aceita as cartas). 
i) Eusébio: 1 João, 1 Pedro, Tiago, Judas, 2 Pedro, 2 e 3 João.

j) Cheltenham/Mommsen: três de João, duas de Pedro.

1) Anfilóquio: Tiago, três de João, duas Pedro, Judas.

m) Cânon Apostólico: Tiago, três de João, Judas, duas de Pedro.

n) João Crisóstomo: "das Epístolas católicas há três" (Tiago, 1 Pedro, 1 João).

o) Relatório de Junílio: 1 Pedro, 1 João, Tiago, 2 Pedro, Judas, duas de João.

p) Cassiodoro oferece duas listas, uma como sendo de Jerônimo, na seguinte ordem: 1 e 2 de Pedro, 1, 2 e 3 de João, Tiago e Judas; e outra como sendo de Agostinho, na seguinte ordem: 1 e 2 de Pedro, 1, 2 e 3 de João, Judas, Tiago.

q) João Salisbury: cita apenas o título: "seguem as 7 Epístolas Canônicas" (aceita as três).

r) Irineu e Cipriano de Cartago: Tiago, 1 Pedro, 1-2 João.

s) Clemente de Alexandria e Dídimo (o Cego): Tiago, 1 Pedro, 1 João, Judas.

t) Tertuliano e versão Peshita: Tiago, 1 Pedro, 1 João.

u) Marcião: recusa todas as cartas católicas, por conseguinte, as três joaninas.

\section{Conclusão}

Realizar estudos acerca dos textos que compreendem e formam o corpus johannicum é, para nós, uma alegria e uma desafio, pois são textos atribuídos a um mesmo autor do NT, João, apóstolo e evangelista, mas com gêneros diversos de literatura: o evangélico, o epistolar e o apocalíptico. Mais ainda, são textos que estão distribuídos e esparsos entre os corpora neotestamentários, o que não nos possibilita encontrá-los todos juntos, como temos em seus demais corpora, ou seja, nos Evangelhos, nas cartas Paulinas e nas cartas Católicas, sendo este último corpus também discutível para alguns.

Embora sejam cinco textos atribuídos ao mesmo autor, o parentesco entre os textos do corpus joanino não é coisa tão fácil de ser estabelecido, pois, além da diversidade de gênero de literatura, há outros dados que por si só são normais e que sempre foram levantados, ou seja, há também uma enorme diferença de estilo, dados, vocabulário, teologia, etc. (TUÑI; ALEGRE, 1999, v. 8, p. 12). Alguns autores preferem falar de "notáveis diferenças" (HARRINGTON, 2002, p. 607); outros também falam de "evidente parentesco e diferenças notáveis" (COTHENET et al., 1988, p. 9); ou ainda há quem fala de "afinidades incontestáveis, acom- 
panhadas de dificuldades" (ZARAGOZA, 2017, p. 5). Tudo isso nos leva a acreditar em mãos redacionais diferentes, como vem apresentado no caso da escola ou comunidade joanina, que teria ajudado na redação final desses cinco textos que formam o corpus joanino: um Evangelho, três Cartas e um Apocalipse. Por outro lado, a Tradição sempre viu uma certa proximidade entre esses textos atribuídos a João, colocando-os sob sua autoridade apostólica (COTHENET et al., 1988, p. 9), mesmo que isso não tenha fornecido condições para que fossem colocados todos juntos, por critérios de autoria. Pelo contrário, ao invés de apresentá-los todos juntos, numa sequência, como temos com as cartas do corpus paulino, desde a Antiguidade a Tradição preferiu seguir pelo critério de gênero de literatura, deixando-os espalhados pelos vários corpora neotestamentários, colaborando para a unidade do mesmo, visto que este é um corpus que faz uma "interface" (GOSWELL, 2018, p. 718.724) com todos demais. E tudo indica que não teremos alterações no cânon nesse sentido, nem no Oriente nem no Ocidente, preferindo deixar a distribuição e o arranjo que temos em nossas Bíblias ainda hoje.

A questão do arranjo e distribuição dos cinco textos joaninos dentro do corpus Novi Testamenti foi uma obra que demandou esforços gigantescos e tempo de amadurecimento e reflexão, antes de se tomar as decisões definitivas no final do séc. IV d.C. (GONZAGA, 2019, p. 412). A Igreja, desde seus primórdios, aceitando as Sagradas Escrituras judaicas, foi delineando seu cânon bíblico, escolhendo e aceitando também outros textos, entre os vários que foram aparecendo da literatura dos apóstolos e discípulos de Cristo, do círculo do primeiro século, inclusive em meio a tantíssimos textos apócrifos, como indica J. F. Faria (2009, p. 63-80). Isto foi fruto de um trabalho árduo, seguindo critérios e confiando na ação do Espírito Santo.

Essa escolha dos livros e estabelecimento do cânon, tal como seu arranjo, não foi tarefa fácil, porque muitos foram os textos apócrifos que surgiram, atribuídos aos vários apóstolos. Esse é o caso de toda a vasta literatura apócrifa atribuída a João, o Apóstolo e Evangelista, surgida já desde o séc. II e que foi aumentando com o tempo, tendo em vista a figura proeminente de João na Igreja Primitiva.

Quando a Igreja decidiu e fechou o seu cânon das Sagradas Escrituras, contendo livros da antiga aliança (AT) e da nova (NT), ela procurou seguir critérios e distribuir seus livros segundo uma série de elementos: autoria, antiguidade, gênero literário, valor, tamanho etc., o que nem sempre foi concorde na aceitação de todos. Aliás, o Ocidente e o Oriente nem sempre foram unânimes em relação $a ̀$ aceitação dos livros e muito menos em relação ao lugar que cada um ocuparia no arranjo de cada corpus do NT. Nesse sentido, como observa Gonzaga, "o arranjo do corpus joanino precisa ser 'montado' pegando livros dos outros corpora" (2019, p. 409), pois 
o Evangelho de João encontra-se no corpus evangeliorum, as três Cartas de João, no corpus catholicum, e o Apocalipse de João, sozinho, no final do cânon neotestamentário.

Enfim, também vale a pena recordar que este é um corpus biblicum que conta com escassez de material, tendo em vista a sua própria dificuldade em tratar a temática ao longo dos séculos e a dificuldade em encontrar a unidade e a autoridade desses textos, desde cedo colocada em cheque. Nesse sentido, um artigo nessa área pode nos ajudar a avançar um pouco mais nesse campo e na produção de material, vistas as necessidades em nossos estudos acadêmicos, bíblicos e teológicos.

\section{Referências}

ÁLVAREZ MAESTRO, J. (Ed.), Taciano, La más antigua vida de Jesús: Diatessaron. Madrid: Edibessa, 2002.

ARAMAS, E. (Ed.). Diatessaron: El Evangelio de Taciano. Maimi: Emmanuel, 2015.

ARAUJO, G. L. A presença da literatura joanina na literatura copta de Nag Hammadi. Revista de Teologia e Ciências da Religião da Unicap, Recife, v. 5, n. 1, p. 213-224, Dez. 2015.

BALLARINI, T. As Epístolas Católicas em Geral. In: BALLARINI, T. Introdução à Bíblia. Petrópolis: Vozes, 1969. v. V/2, p. 281-456.

BORING, M. E. Comunidade Joanina e Escola Joanina. In: BORING, M. E. Uma Introdução ao Novo Testameto- - História, Literatura, Teologia: Cartas Católicas, Sinóticos e Joaninos. São Paulo: Academia Cristã, 2016. v. II, p. 1120-1140.

BROWN, R. E. As Igrejas dos Apóstolos. São Paulo: Paulinas, 1982.

BROWN, R. E. A Comunidade do Discípulo Amado. São Paulo: Paulus, 2003.

BROWN, R. E.; COLLINS, R. F. Canonicidade. In: BROWN, R. E.; FITZMYER, J. A.; MURPHY, R. E. (Eds.). Novo Comentário Bíblico São Jerônimo: Novo Testamento e Artigos Sistemáticos. Santo André: Academia Cristã; São Paulo: Paulus, 2011. p. $907-946$.

BRUCE, F. F. Pedro, Estêvvão, Tiago e João: Estudos do cristianismo não-paulino. São Paulo: Shedd, 2005.

BRUCE, F. F. O Cânon das Escrituras. São Paulo: Hagnos, 2013.

CHAPA, J.; GONZÁLES-ALANO, P. Escritos Joánicos y Cartas Católicas. Pamplona: EUNSA, 2018.

CHIBERTI, G. Opera Giovanea. Torino: Elledici, 2003.

COLLINS, A. Y. Apocalipse. In: BROWN, R. E.; FITZMYER, J. A.; MURPHY, R. E. (Eds.). Novo Comentário Bíblico São Jerônimo: Novo Testamento e Artigos Sistemáticos. Santo André: Academia Cristã; São Paulo: Paulus, 2011. p. 835-874. 
COTHENET, E. et al. Os Escritos de João e a Epístola aos Hebreus. São Paulo: Paulinas, 1988.

CULlMANN, O. As Cartas Católicas, In: CULLMANN, O. A Formação do Novo Testamento. São Leopoldo: Sinodal-Est, 2012. p. 69-83.

DAVIDS, P. H. The Catholic Epistles as a Canonical Janus: A New Testament Glimpse into Old and New Testament Canon Formation. Bulletin for Biblical Research, Pennsylvania, v. 19, n. 3, p. 403-416, 2009.

ERBETTA, M. (Cura.). Gli Apocrifi del Nuovo Testamento: Lettere e apocalissi. Casale Monferrato: Marietti, 1998. v. II

ERBETTA, M. (Cura.). Gli Apocrifi del Nuovo Testamento: Vangeli, Testi giudeo-cristiani e gnostici. Casale Monferrato: Marietti, 1999. v. I/1.

ERBETTA, M. (Cura.). Gli Apocrifi del Nuovo Testamento: Vangeli, Infanza, Passione, Assunzione di Maria. Casale Monferrato: Marietti, 2003. v. I/2.

ERBETTA, M. (Cura.). Gli Apocrifi del Nuovo Testamento, Atti e leggende. Casale Monferrato: Marietti, 2015. v. III.

EUSEBIO de Cesarea. Historia Eclesiástica. Madrid: BAC, 2008.

FARIA, J. F. Bíblia Apócrifa, a outra face do cristianismo. Cadernos Patrísticos, Florianópolis, v. IV, n. 7, p. 63-80, Mai. 2009.

FEUILLET, A. Os Escritos Joaninos. In: ROBERT, A.; FEUILLET, A. Introdução à Bíblia. Vozes: Petrópolis, 1968. v. IV, p. 225-352.

FITZMYER, J. A. Introdução às Epístolas do Novo Testamento. In: BROWN, R. E.; FITZMYER, J. A.; MURPHY, R. E. (Eds.). Novo Comentário Bíblico São Jerônimo: Novo Testamento e Artigos Sistemáticos. Santo André: Academia Cristã; São Paulo: Paulus, 2011. p. 399-405.

GONZAGA, W. As Cartas Católicas no Cânon do Novo Testamento. Perspectiva Teológica, Belo Horizonte, v. 49, n. 2, p. 421-444, Mai./Ago. 2017a.

GONZAGA, W. O Corpus Paulinum no Cânon do Novo Testamento. Atualidade Teológica, Rio de Janeiro, v. 21, n. 55, p. 19-41, Jan./Abr. 2017b.

GONZAGA, W. Compêndio do Cânon Bíblico: Listas bilíngues dos Catálogos Bíblicos, Antigo Testamento, Novo Testamento e Apócrifos. Rio de Janeiro: EdPUC-Rio; Petrópolis: Vozes, 2019.

GOSWELL, G. The Order of the Books of the New Testament. Journal of the Evangelical Theological Society, Scottsdale, v. 53, n. 2, p. 225-241, Jun. 2010.

GOSWELL, G. The Johannine Corpus and the unity of the New Testament Canon. Journal of the Evangelical Theological Society, Scottsdale, v. 61, n. 4, p. 717-733, Dec. 2018.

HAAG, H. A Palavra de Deus transformada em Livro na Sagrada Escritura. In: FEINER, J.; LOEHRER, M. Mysterium Salutis: compêndio de dogmática histórico-salvífica. Petrópolis: Vozes, 1971. v. I/2. p. 53-186.

HARRINGTON, W. J. Chave para a Bíblia: a revelação, a promessa, a realização. São Paulo: Paulus, 2002. 
HILL, C. E. The Johannine Corpus in the Early Church. Oxford: Oxford University Press, 2006.

KÜMMEL, W. G. Introdução ao Novo Testamento. São Paulo: Paulinas, 1982.

MAGRI, A. Notes sur la réception de l'Évangile de Jean au IIe siècle. L'idée gnostique de Canon. In: ARANGIONE, G.; JUNOD, E.; NORELLI, E. (Dir.). Le Canon du Nouveau Testament: Regards nouveaux sur l'histoire de sa formation. Genève: Labor et Fides, 2005, p. 116-140.

MANNUCCI, V. Il Canone delle Scritture. In: FABRIS, R. Introduzione Generale alla Bibbia. Torino: Elledici, 1999. p. 375-395.

MANSON, T. W. Entry into Membership of the Early Church. Journal of Theological Studies, Oxford, v. 48, n. 189-190, p. 25-33, Jan. 1947.

MCDONALD, L. M. A Origem da Bíblia. São Paulo: Paulus, 2013.

METZGER, B. M. The Canon of the New Testament: Its Origen, Development, and Significance. Oxford: Clarendon Press, 2009.

NESTLE-ALAND. Novum Testamentum Graece. 28. Aufl. Stuttgart: Deutsche Bibelgesellchaft, 2012.

O’CALLAGHAN, J. A formação do Novo Testamento. São Paulo: Paulinas, 2000.

ONG, H. T. The Gospel from a Specific Community but for All Christians: Understanding the Johannine Community as a "Community of Practice". In: PORTER, S. E.; ONG, H. T. (Eds.). The Origins of John's Gospel: Johannine Studies 2. Leiden: Brill, 2016. p. 101-112.

PENNA, R. A formação do Novo Testamento e suas três dimensões. São Paulo: Loyola, 2014.

PERKINS, P. Evangelho segundo João. In: BROWN, R. E.; FITZMYER, J. A.; MURPHY, R. E. (Eds.). Novo Comentário Bíblico São Jerônimo: Novo Testamento e Artigos Sistemáticos. Santo André: Academia Cristã; São Paulo: Paulus, 2011a. p. 731-816.

PERKINS, P. As Epístolas Joaninas. In: BROWN, R. E.; FITZMYER, J. A.; MURPHY, R. E. (Eds.). Novo Comentário Bíblico São Jerônimo: Novo Testamento e Artigos Sistemáticos. Santo André: Academia Cristã; São Paulo: Paulus, 2011b. p. 817-834.

PETERSEN, W. L. Canonicité, autorité ecclésiastique et Diatessaron de Tatien. In: ARANGIONE, G.; JUNOD, E.; NORELLI, E. (Dir.). Le Canon du Nouveau Testament. Regards nouveaux sur l'histoire de sa formation. Genève: Labor et Fides, 2005. p. $87-116$.

PORTER, S. E. The Date of John's Gospel and Its Origins. In: PORTER, S. E.; ONG, H. T. (Eds.). The Origins of John's Gospel: Johannine Studies 2. Leiden: Brill, 2016. p. 11-29.

PROENÇA, E. (Org.). Apócrifos e Pseudo-epígrafos da Bíblia. São Paulo: Fonte Editorial, 2010. v. 1.

PROENÇA, E. (Org.). Apócrifos e Pseudo-epígrafos da Bíblia. São Paulo: Fonte Editorial, 2012. v. 2. 
SACHI, A. Lettere paoline e altre lettere. Torino: Elledici, 1995.

TAYLOR, T. S. The Authorship of the Johannine Epistles. Oxford: Spring, 2011.

THEISSEN, G. O Novo Testamento. Petrópolis: Vozes, 2007.

TUÑI, J.-O.; ALEGRE, X. Escritos Joanicos e Cartas Católicas: Introdução ao Estudo da Bíblia. São Paulo: Ave Maria, 1999. v. 8.

WESTCOTT, B. F.; HORT, F. J. The New Testament in The Original Greek. London: Macmillan and Co. Limited, 1906.

ZARAGOZA, N. F. Corpus Joánico y Epístolas Católicas. Madrid: Universidad San Dámaso, 2017.

Artigo submetido em 18.05.2020 e aprovado em 21.10.2020.

Waldecir Gonzaga é Doutor em Teologia Bíblica pela Pontifícia Universidade Gregoriana (Roma, Itália), com Pós-Doutorado pela Faculdade Jesuíta de Filosofia e Teologia (FAJE). Diretor do Departamento de Teologia da PUC-Rio e professor de Teologia Bíblica na mesma Instituiço. Orcid.org/0000-0001-5929-382X. E-mail: waldecir@puc-rio.br

Endereço: Rua Marquês de São Vicente, 225, 11ํandar

Gávea

22451-900 Rio de Janeiro - RJ 